\section{TINJAUAN YURIDIS PERANAN MENTERI \\ KEUANGAN DALAM PENGAJUAN \\ PERMOHONAN PERNYATAAN PAILIT \\ TERHADAP DEBITOR BUMN ${ }^{1}$ \\ Oleh : Moraya Hutajulu ${ }^{2}$ \\ Flora Pricilla Kalalo ${ }^{3}$ \\ Roosje Lasut ${ }^{4}$}

\begin{abstract}
ABSTRAK
Tujuan dilakukannya penelitian ini yaitu untuk mengetahui bagaimana Pengaturan Kepailitan Terhadap BUMN dan bagaimana Peranan Menteri Keuangan Dalam Pengajuan Permohonan Pernyataan Pailit Terhadap Debitor BUMN, yang dengan metode penelitian hukum normatif disimpulkan: 1. Pengaturan untuk mempailitkan suatu Badan Usaha Milik Negara (BUMN) diatur secara keseluruhan dalam Undang-Undang Nomor 37 Tahun 2004 tentang Kepailitan dan Penundaan Kewajiban Pembayaran Utang. Lebih spesifik pengaturannya diatur dalam Pasal 2 ayat (5) Undang-Undang Nomor 37 Tahun 2004. Pengaturan Kepailitan terhadap BUMN memiliki Kekaburan atau multitafsir terkait penjelasan Pasal 2 ayat (5) mengenai BUMN yang bergerak dibidang kepentingan publik, Undang-Undang Kepailitan tidak memberikan batasan kriteria kepentingan publik secara tegas, hanya menggunakan batasan besaran dan asal modalnya tetapi tidak menjelaskan secara tegas bahwa yang dimaksud dengan kepentingan publik adalah BUMN Perum. Terdapatnya disharmonisasi Undang-Undang mengenai kewenangan Menteri Keuangan dalam mempailitkan BUMN Perum juga haruslah memperhatikan asas Lex posteriori derogate legi priori yakni peraturan yang baru mengalahkan atau melumpuhkan peraturan yang lama. 2. Menteri Keuangan memiliki peranan penting dalam pengajuan permohonan peryataan pailit terhadap Badan Usaha Milik Negara (BUMN). Menteri keuangan memiliki peranan untuk mempailitkan suatu BUMN yang bergerak dibidang kepentingan publik (perum) untuk kepentingan perekonomian Negara, atau menjadi salah satu cara untuk menyelamatkan
\end{abstract}

\footnotetext{
${ }^{1}$ Artikel Skripsi.

${ }^{2}$ Mahasiswa pada Fakultas Hukum Unsrat, NIM. 16071101166

${ }^{3}$ Fakultas Hukum Unsrat, Doktor IImu Hukum

${ }^{4}$ Fakultas Hukum Unsrat, Magister IImu Hukum
}

perekonomian Negara melalui kepailitan. Peranan Menteri Keuangan dalam kepailitan BUMN sesuai dengan Undang-Undang Nomor 37 tahun 2004 tentang Kepailitan dan Penundaan Kewajiban Pembayaran Utang adalah sebagai pemohon pernyataan pailit terhadap Badan Usaha Milik Negara (BUMN) yang bergerak di bidang kepentingan Publik atau Perum. Dalam hal kreditor BUMN yang akan mengajukan pailit harus terlebih dahulu mengajukan permohonan kepada Menteri keuangan melalui Biro Hukum bagian Hukum Kekayaan Negara, Perusahaan, dan Informasi hukum yang kemudian akan disampaikan kepada Menteri Keuangan untuk segera mengajukan permohonan pernyataan pailit terhadap BUMN kepada Ketua Pengadilan.

Kata kunci: pailit; menteri keuangan;

\section{PENDAHULUAN}

\section{A. Latar Belakang}

Dalam Pasal 2 ayat (5) Undang-Undang Nomor 37 Tahun 2004 Tentang Kepailitan dan Penundaan Kewajiban Pembayaran Utang disebutkan bahwa "Dalam hal Debitor adalah Perusahaan Asuransi, Perusahaan Reasuransi, Dana Pensiun, atau Badan Usaha Milik Negara yang bergerak di bidang kepentingan publik, permohonan pernyataan pailit hanya dapat diajukan oleh Menteri Keuangan". ${ }^{5}$ Dalam penjabaran tersebut Undang-Undang tidak menjabarkan secara detail mengingat bentuk BUMN Jika mengacu pada Pasal 9 UU No 19 Tahun 2003 Tentang Badan Usaha Milik Negara, BUMN terdiri dari Persero dan Perum. ${ }^{6}$ Sehingga dalam praktiknya terdapat perbedaan persepsi terkait bentuk BUMN yang dapat dipailitkan oleh Menteri Keuangan.

\section{B. Rumusan Masalah}

1. Bagaimana Pengaturan Kepailitan Terhadap BUMN ?

2. Bagaimana Peranan Menteri Keuangan Dalam Pengajuan Permohonan Pernyataan Pailit Terhadap Debitor BUMN

\section{Metode Penelitian}

\footnotetext{
${ }^{5}$ Pasal 2 ayat (5) Undang-undang Nomor 37 tahun 2004 Tentang Kepailitan dan Penundaan Kewajiban Pembayaran Utang

${ }^{6}$ Pasal 9 Undang-Undang Nomor 19 tahun 2003 Tentang Badan Usaha Milik Negara
} 
Metode penelitian yang digunakan dalam penelitian ini adalah metode penelitian yuridis normatif.

\section{PEMBAHASAN}

\section{A. Pengaturan Kepailitan Terhadap Bumn}

Pengaturan Kepailitan terhadap Badan Usaha Milik Negara (BUMN) diatur dalam Undang-Undang Nomor 37 Tahun 2004 Tentang Kepailitan dan Penundaan Kewajiban Pembayaran Utang. Dalam Undang-Undang Nomor 37 Tahun 2004 Tentang Kepailitan dan Penundaan Kewajiban Pembayaran Utang pengaturan tentang kepailitan terhadap Badan Usaha Milik Negara (BUMN) diatur spesifik dalam Pasal 2 ayat (5) Undang-Undang Nomor 37 Tahun 2004 tentang Kepailitan dan Penundaan Kewajiban Pembayaran Utang. Dalam pasal tersebut menyebutkan bahwa dalam hal debitor adalah Perusahaan Asuransi, Perusahaan Reasuransi, Dana Pensiun, atau Badan Usaha Milik Negara yang bergerak di bidang kepentingan publik, permohonan pernyataan pailit hanya dapat diajukan oleh Menteri Keuangan. ${ }^{7}$

Berdasarkan Pengaturan Kepailitan terhadap BUMN yang telah diuraikan diatas penulis merasa perlu untuk menjelaskan/menjabarkan maksud atau makna dari Badan Usaha Milik Negara yang bergerak dibidang kepentingan publik, agar jelas memahami tentang Pengaturannya, Peranan Menteri Keuangan dalam kepailitan terhadap BUMN yang bergerak dibidang kepentingan publik, karena berdasarkan ketentuan peraturan perundangundangan terkait BUMN terdapat 2 (dua) jenis BUMN, yaitu : BUMN dalam bentuk Persero dan BUMN dalam bentuk Perum.

\section{Badan Usaha Milik Negara (BUMN) yang bergerak dibidang Kepentingan Publik}

Undang-Undang No. 19 Tahun 2003 Tentang Badan Usaha Milik Negara (BUMN) mengenal dua bentuk Badan Usaha Milik Negara (BUMN), yaitu Perusahaan Perseroan (Persero) dan Perusahaan Umum (Perum). ${ }^{8}$ Pasal 1 angka 2 Undang-Undang BUMN menyebutkan bahwa Perusahaan Perseroan, yang selanjutnya disebut Persero adalah Badan Usaha Milik Negara yang berbentuk perseroan terbatas yang modalnya terbagi dalam saham yang

\footnotetext{
${ }^{7}$ Pasal 2 ayat 5 UU No.37 Tahun 2004.

${ }^{8}$ Pasal 9 UU No. 19 Tahun 2003.
}

seluruh atau paling sedikit $51 \%$ (lima puluh satu persen) sahamnya dimiliki Negara Republik Indonesia yang tujuan utamanya mengejar keuntungan. ${ }^{9}$ sedangkan Perusahaan Umum, yang selanjutnya disebut Perum, adalah Badan Usaha Milik Negara yang seluruh modalnya dimiliki negara dan tidak terbagi atas saham, yang bertujuan untuk kemanfaatan umum berupa penyediaan barang dan/atau jasa yang bermutu tinggi dan sekaligus mengejar keuntungan berdasarkan prinsip pengelolaan perusahaan. ${ }^{10}$

Berdasarkan uraian diatas penulis berpendapat bahwa yang dimaksud dengan Badan Usaha Milik Negara (BUMN) yang bergerak dibidang kepentingan publik adalah Perusahaan Umum (Perum) dikarenakan bersesuaian penjelasan Pasalnya antara Pasal 1 ayat (4) Undang-Undang Nomor 19 Tahun 2003 dengan Penjelasan Pasal 2 ayat 5 UU No. 37 Tahun 2004 Tentang Kepailitan dan Penundaan Kewajiban Pembayaran Utang.

Penjelasan Pasal 2 ayat 5 UU No. 37 Tahun 2004 Tentang Kepailitan dan Penundaan Kewajiban Pembayaran Utang adalah sebagai berikut: ${ }^{11}$

"Yang dimaksud dengan "Perusahaan Asurasi" adalah Perusahaan Asuransi Jiwa dan Perusahaan Asuransi Kerugian.

Perusahaan Asuransi dan Perusahaan Reasuransi adalah Perusahaan Asuransi dan Perusahaan Reasuransi sebagaimana diaksud dalam Undang-Undang yang mengatur mengenai Usaha Perasuransian.

Kewenangan untuk mengajukan permohonan pernyataan pailit bagi Perusahaan Asuransi atau Perusahaan Reasuransi sepenuhnya ada pada Menteri Keuangan.

Ketentuan ini diperlukan untuk membangun tingkat kepercayaan masyarakat terhadap Perusahaan Asuransi dan Perusahaan Reasuransi sebagai Lembaga pengelola risiko dan sekaligus sebagai Lembaga pengelola dana masyarakat yang memiliki kedudukan strategis dalam pembangunan dan kehidupan perekonomian.

Yang dimaksud dengan "Dana Pensiun" adalah Dana Pensiun sebagaimana dimaksud

\footnotetext{
${ }^{9}$ Pasal 1 ayat (2) UU No. 19 Tahun 2003.

${ }_{10}^{10}$ Pasal 1 ayat (4) UU No. 19 Tahun 2003.

${ }^{11}$ Lihat penjelasan Pasal 2 ayat (5) UU No. 37 Tahun 2004
} 
dalam Undang-Undang yang mengatur mengenai Dana Pensiun.

Kewenangan untuk mengajukan pailit bagi Dana Pensiun, sepenuhnya ada pada Menteri Keuangan. Ketentuan ini diperlukan untuk membangun tingkat kepercayaan masyarakat terhadap Dana Pensiun, mengingat Dana Pensiun mengelola dana masyarakat dalam jumlah besar dan dana tersebut merupakan hak dari peserta yang banyak jumlahnya.

Yang dimaksud dengan "Badan Usaha Milik Negara yang bergerak di bidang kepentingan publik" adalah badan usaha milik negara yang seluruh modalnya dimiliki negara dan tidak terbagi atas saham.

Kewenangan Menteri Keuangan dalam pengajuan permohonan pailit untuk instansi yang berbeda di bawah pengawasannya seperti kewenangan Bank Indonesia sebagaimana dimaksud pada ayat (3) dan Badan Pengawas Pasar Modal sebagaimana dimaksud pada ayat (4)."

Berdasarkan penjelasan Pasal 2 ayat (5) Undang-Undang Nomor 37 Tahun 2004 Tentang Kepailitan dan Penundaan Kewajiban Pembayaran Utang, Yang dimaksud dengan Badan Usaha Milik Negara yang bergerak dibidang kepentingan publik adalah BUMN yang seluruh modalnya dikuasai oleh negara dan tidak terbagi atas saham, maka permohonan pernyataan pailit terhadap BUMN yang modalnya terbagi dalam saham, yang seluruh atau sebagian modalnya dimiliki oleh negara, yaitu BUMN yang berbentuk Perusahaan Persero atau Persero tidak termasuk yang dimaksud dengan ketentuan Pasal 2 ayat (5) Undang-Undang Nomor 37 Tahun 2004 Tentang Kepailitan dan Penundaan Kewajiban Pembayaran Utang, sehingga permohonan pernyataan pailitnya dapat diajukan secara langsung oleh kreditornya, sedangkan Badan Usaha Milik Negara (BUMN) yang berbentuk Perusahaan Umum (Perum) permohonan pernyataan pailitnya harus diajukan oleh Menteri Keuangan karena Perum tidak terbagi atas saham dan seluruh modalnya dikuasai oleh Negara.

Pada praktiknya, banyak BUMN yang berbentuk Persero (terbagi atas saham) menyelenggarakan usaha dibidang kepentingan publik. Dasar dari banyaknya BUMN yang berbentuk Persero juga menjalankan kepentingan publik dapat dilihat dari Tujuan pendirian Badan Usaha Milik Negara itu sendiri. Berdasarkan Undang-Undang Nomor 19 Tahun 2003 Tentang Badan Usaha Milik Negara tujuan pendirian BUMN adalah sebagai berikut: ${ }^{12}$

a. Memberikan sumbangan bagi perkembangan perekonomian nasional pada umumnya dan penerimaan negara pada khususnya;

b. Mengejar keuntungan;

c. Menyelenggarakan kemanfaatan umum berupa penyediaan barang dan/atau jasa yang bermutu tinggi dan memadai bagi pemenuhan hajat hidup orang banyak;

d. Menjadi perintis kegiatan-kegiatan usaha yang belum dapat dilaksanakan oleh sektor swasta dan koperasi; dan turut aktif memberikan bantuan kepada pengusaha golongan ekonomi lemah, koperasi, dan masyarakat.

Berdasarkan ketentuan tersebut seluruh BUMN yang ada pada hakikatnya bergerak dalam sektor kepentingan publik untuk menyelenggarakan kemanfaatan umum berupa penyediaan barang dan/atau jasa yang bermutu tinggi dan memadai bagi pemenuhan hajat hidup orang banyak. Hal ini menunjukkan bahwa bukan hanya BUMN Perum saja yang menyelenggarakan kepentingan publik, melainkan BUMN Persero juga menyelanggarakan kepentingan publik. Tetapi jika mengacu pada Penjelasan Pasal 2 ayat (5) Undang-Undang Nomor 37 Tahun 2004 Tentang Kepailitan dan Penundaan Kewajiban Pembayaran Utang, BUMN yang berbentuk Persero tidak termasuk kategori BUMN yang bergerak dibidang kepentingan publik dikarenakan modalnya terbagi atas saham.

Prof.Dr.Rahayu Hartini, S.H., M.Si., M. Hum berpendapat bahwa batasan yang diberikan oleh Undang-Undang Kepailitan dan Penundaan Kewajiban Pembayaran Utang mengenai maksud "Badan Usaha Milik Negara yang bergerak dibidang kepentingan publik", kurang jelas atau tidak tepat karena hanya menggunakan batasan atau ukuran besaran dan asalnya modal serta bentuknya tetapi tidak menjelaskan apa itu kepentingan publik itu sendiri, sehingga ini masih membuka peluang penafsiran lainnya yang dapat memberi

\footnotetext{
12 Pasal 22 UU Nomor 19 Tahun 2003
} 
peluang untuk terjadinya penyimpangan hukum dalam praktiknya. ${ }^{13}$

Menurut Prof.Dr.Rahayu Hartini tersebut bahwa batasan Maksud dari BUMN yang bergerak dibidang kepentingan publik kurang jelas atau kabur sehingga dapat menumbulkan multi tafsir terkait makna dari BUMN yang bergerak dibidang kepentingan publik tersebut karena hanya memuat batasan besar, asal modal dari BUMN tersebut.

Belum adanya batasan atau parameter yang jelas mengenai makna dari kepentingan publik pada BUMN yang bergerak dibidang kepentingan publik dan rumusan yang multitafsir dalam Pasal 2 ayat (5) UndangUndang Nomor 37 Tahun 2004 Tentang Kepailitan dan Penundaan Kewajiban Pembayaran Utang beserta penjelasannya menyebabkan terjadi perbedaan pendapat di kalangan hakim dalam menangani permohonan kepailitan untuk Badan Usaha Milik Negara. Hal tersebut dapat dilihat dari Kasus PT. Dirgantara Indonesia (Persero) yang diajukan permohonan pailit oleh 3 orang mantan pekerja PT. DI Persero yang pada pengadilan Niaga majelis hakim mengabulkan permohonan Pailit karena mantan pekerja dapat mengajukan pailit dikarenakan PT. DI adalah BUMN yang berbentuk Persero sedangkan pada tingkat Kasasi Majelis hakim menolak Permohonan permohonan karena menganggap PT. DI Persero adalah BUMN yang bergerak dibidang kepentingan publik.

Disamping terdapatnya kekaburan atau multitafsir terhadap penjelasan Pasal 2 ayat (5), Pengaturan Kepailitan Terhadap BUMN yang bergerak dibidang kepentingan publik haruslah merujuk pada Pasal 2 ayat (5) Undang-Undang Nomor 37 Tahun 2004 Tentang Kepailitan dan Penundaan Kewajiban Pembayaran Utang, sesuai dengan penjelasan Pasalnya bahwa yang dimaksud dengan BUMN yang bergerak dibidang kepentingan publik adalah BUMN yang seluruh modalnya dikuasai oleh negara dan tidak terbagi atas saham merupakan BUMN yang berbentuk Perusahaan Umum (Perum).

Berdasarkan uraian diatas, apabila BUMN yang berbentuk Perusahaan Umum (Perum) maka yang memiliki Peranan penting terhadap Permohonan Pailit adalah Menteri Keuangan, sedangkan apabila BUMN tersebut berbentuk

\footnotetext{
${ }^{13}$ Rahayu Hartini, Op.Cit, hlm. 187
}

Persero tidak harus melalui Menteri Keuangan dan dapat dilakukan oleh Debitur itu sendiri atau oleh krediturnya.

Jadi apabila debiturnya itu Perum, terhadap Pasal 2 ayat (5) berlaku lex specialist terhadap Pasal 2 ayat (1) Undang-Undang Kepailitan dan Penundaan Kewajiban Pembayaan Utang, akan tetapi apabila debiturnya adalah Persero maka yang berlaku sebagai lex specialist adalah Pasal 2 ayat (1) Undang-Undang Nomor 37 Tahun 2004 Tentang Kepailitan dan Penundaan Kewajiban Pembayaran Utang. ${ }^{14}$

Namun, membicarakan tentang Pengaturan Kepailitan terhadap BUMN harus juga memperhatikan Undang-Undang BUMN, dalam Pasal 55 ayat (1) "direksi hanya dapat mengajukan permohonan ke pengadilan negeri agar Perum dinyatakan pailit berdasarkan persetujuan Menteri". Dalam pasal tersebut disebutkan bahwa permohonan pernyataan pailit terhadap BUMN Perum dapat diajukan oleh Direksi, sedangkan Menteri Keuangan hanyalah pihak yang memberikan persetujuan kepada Direksi saja. Ini berarti Menteri Keuangan juga bukanlah satu-satunya pihak yang dapat mengajukan permohonan pailit terhadap BUMN Perum. Padahal UndangUndang Kepailitan menegasakan bahwa Menteri Keuangan adalah satu-satunya pihak yang dapat mengajukan pernyataan pailit terhadap BUMN yang bergerak di bidang kepentingan publik. Dalam Undang-Undang BUMN tidak mendeskripsikan maksud dari Pasal 55 ayat (1) Undang-Undang Nomor 19 tahun 2003 dalam penjelasan pasalnya, sehingga dapat menyebabkan timbulnya tafsir baru bahwa Menteri Keuangan tidak berperan aktif dalam Kepailitan Badan Usaha Milik Negara (BUMN) melainkan direksilah yang berperan aktif dalam Kepailitan Badan Usaha Milik Negara (BUMN).

\section{Terdapatnya Disharmonisasi antara Pasal 55 Undang-Undang Nomor 19 Tahun 2003 dengan Pasal 2 ayat (5) Undang-Undang Nomor 37 Tahun 2004 Tentang Kepailitan dan Penundaan Kewajiban Pembayaran Utang}

Pada Bab III bagian keempat UndangUndang Nomor 19 tahun 2003 Tentang Badan Usaha Milik Negara mengenai kewenangan

\footnotetext{
${ }^{14}$ Rahayu Hartini, Loc.cit
} 
Menteri, tidak menyebutkan secara jelas mengenai keterlibatan Menteri keuangan dalam hal kepailitan. Kewenangan Menteri $:^{15}$

Pasal 38 UU No. 19 Tahun 2003 tentang BUMN :

(1) Menteri memberikan persetujuan atas kebijakan pengembangan usaha Perum yang diusulkan oleh Direksi.

(2) Kebijakan pengembangan usaha sebagaimana dimaksud dalam ayat (1) diusulkan oleh Direksi kepada Menteri setelah mendapat persetujuan dari Dewan Pengawas.

(3) Kebijakan sebagaimana dimaksud dalam ayat (1) ditetapkan sesuai dengan maksud dan tujuan Perum yang bersangkutan.

Pasal 39 UU No. 19 Tahun 2003 Tentang Badan Usaha Milik Negara :

"Menteri tidak bertanggung jawab atas segala akibat perbuatan hukum yang dibuat Perum dan tidak bertanggung jawab atas kerugian perum melebihi nilai kekayaan negara yang telah dipisahkan kedalam Perum, kecuali apabila Menteri:

baik langsung maupun tidak langsung dengan itikad buruk memanfaatkan Perum semata-mata untuk kepentingan pribadi; terlibat dalam perbuatan melawan hukum yang dilakukan oleh Perum; atau langsung maupun tidak langsung secara melawan hukum menggunakan kekayaan Perum."

Pasal 40 UU No. 19 Tahun 2003 Tentang Badan Usaha Milik Negara :

"Ketentuan mengenai tata cara pemindahtanganan, pembebanan atas aktiva tetap Perum, serta penerimaan pinjaman jangka menengah/Panjang dan pemberian pinjaman dalam bentuk dan cara apa pun, serta ridak menagih lagi dan menghapuskan dari pembukuan piutang dan persediaan barang oleh Perum diatur dengan Keputusan Menteri."

Berdasarkan kewenangan Menteri dalam Undang-Undang No. 19 Tahun 2003 Tentang Badan Usaha Milik Negara tersebut dapat dikatakan bahwa Menteri Keuangan tidak berperan aktif dalam Kepailitan BUMN Perum, Sementara dalam Undang-Undang Nomor 37 Tahun 2004 Tentang Kepailitan dan Penundaan Kewajiban Pembayaran Utang hanya Menteri

\footnotetext{
${ }^{15}$ Pasal 38, Pasal 39, Pasal 40 UU No. 19 Tahun 2003
}

Keuangan lah yang berperan aktif, mengajukan permohonan pailit terhadap Badan Usaha Milik Negara (BUMN) Perum.

Dalam menyelesaikan permasalahan konflik antar norma hukum (antinomi hukum), maka berlakulah asas-asas penyelesaian konflik (asas preferensi), yaitu : ${ }^{16}$

1. Lex superiori derogate legi inferiori, yaitu peraturan perundang-undangan yang lebih tinggi akan melumpuhkan peraturan perundang-undangan yang lebih rendah

2. Lex specialis derogate legi generali, yaitu peraturan yang khusus akan melumpuhkan peraturan yang umum sifatnya atau peraturan yang khususlah yang harus didahulukan

3. Lex posteriori derogate legi priori, yaitu peraturan yang baru mengalahkan atau melumpuhkan peraturan yang lama.

Pertentangan peraturan antara Pasal 2 ayat (5) Undang-Undang Nomor 37 Tahun 2004 tentang Kepailitan dan Penundaan Kewajiban Pembayaran Utang dengan Pasal 55 ayat (1) Undang-Undang Nomor 19 Tahun 2003 Tentang Badan Usaha Milik Negara dapat diselesaikan dengan salah satu asas preferensi diatas, yaitu asas Lex posteriori derogate legi priori (Peraturan yang baru mengalahkan peraturan yang lama), asas ini sangat tepat digunakan untuk menjawab permasalahan dari disharmonisasi kedua Undang-Undang ini, karena Undang-Undang Nomor 37 Tahun 2004 Tentang Kepailitan dan Penundaan Kewajiban Pembayaran Utang lebih baru daripada Undang-Undang Nomor 19 Tahun 2003 Tentang Badan Usaha Milik Negara.

Berdasarkan Asas Lex posteriori derogate legi priori penulis menyimpulkan bahwa Menteri Keuangan yang berwewenang dan berperan aktif dalam mengajukan Permohonan Pernyataan Pailit terhadap Badan Usaha Milik Negara (BUMN) yang bergerak di bidang kepentingan publik (Perum).

Permohonan pernyataan pailit terhadap Badan Usaha Milik Negara (BUMN) yang bergerak di bidang kepentingan publik harus diajukan oleh Menteri Keuangan, dan apabila BUMN berbentuk Persero yang ingin diajukan

16 Sudikno Mertokusumo, Mengenal Hukum (Suatu Pengantar), Cetakan ketiga, Yogyakarta: Liberty, 2002, hlm. 85-87 
permohonan pailit dapat diajukan langsung oleh kreditor atau debitor itu sendiri tanpa harus melalui Menteri Keuangan. selanjutnya untuk mengenai pengaturan kepailitan Badan Usaha Milik Negara (BUMN) secara keseluruhan haruslah merujuk pada Pasal 2 ayat (5) dan keseluruhan Undang-Undang Nomor 37 Tahun 2004 Tentang Kepailitan dan Penundaan Kewajiban Pembayaran Utang, yakni BUMN yang bergerak dibidang kepentingan Publik adalah BUMN Perum yang dapat diajukan pailit oleh Menteri Keuangan.

\section{B. Peranan Menteri Keuangan Dalam Pengajuan Permohonan Pernyataan Pailit Terhadap Debitor Badan Usaha Milik Negara (BUMN)}

Menteri Keuangan bertindak atas nama Negara dan dapat mempailitkan suatu Badan Usaha Milik Negara (BUMN) yang bergerak dibidang kepentingan publik dalam hal ini adalah BUMN yang berbentuk Perusahaan Umum (Perum) untuk kepentingan perekonomian Negara, atau menjadi salah satu cara untuk menyelamatkan perekonomian Negara melalui kepailitan, karena yang mengetahui perekonomian negara secara keseluruhan adalah Menteri Keuangan. Peranan Menteri Keuangan dalam kepailitan BUMN sesuai dengan Undang-Undang Nomor 37 tahun 2004 tentang Kepailitan dan Penundaan Kewajiban Pembayaran Utang adalah sebagai pemohon pernyataan pailit terhadap Badan Usaha Milik Negara (BUMN) yang bergerak di bidang kepentingan Publik atau Perum. Apabila kreditor dari Badan Usaha Milik Negara (BUMN) yang ingin mengajukan permohonan pailit harus terlebih dahulu memohon kepada Menteri Keuangan agar Menteri Keuangan mengajukan permohonan pernyataan Pailit terhadap BUMN tersebut. Peranan Menteri Keuangan dalam mempailitkan BUMN sangat beriringan dengan tahapan-tahapan atau proses-proses yang dilakukan oleh Menteri Keuangan dalam mempailitkan suatu BUMN.

\section{Proses Pengajuan Permohonan Pernyataan Pailit terhadap BUMN oleh Menteri Keuangan}

Badan Usaha Milik Negara (BUMN) yang bergerak dibidang kepentingan publik atau BUMN yang berbentuk Perusahaan Umum yang akan diajukan Pailit oleh Menteri Keuangan harus mengacu pada Undang-Undang Nomor 37 Tahun 2004 Tentang Kepailitan dan Penundaan Kewajiban Pembayaran Utang. Tahapan yang akan dilakakukan oleh Menteri Keuangan adalah menilai sautu BUMN tersebut apakah sudah dalam keadaan Insoleven atau sudah dapat memenuhi syarat kepailitan.

Menurut uraian Goodman Law, Insolvensi merupakan suatu keadaan keuangan, yaitu keadaan keuangan yang terjadi apabila utangutang (tidak hanya satu utang saja) dari Debitur melebihi asetnya. ${ }^{17}$ Dari penjelasan tersebut Menteri Keuangan harus memberikan penilaian terhadap Badan Usaha Milik Negara (BUMN) yang berbentuk Perusahaan Umum (Perum) yang akan diajukan Permohonan Pailitnya apakah sudah dalam keadaan Insolven atau tidak.

Menteri Keuangan juga akan memperhatikan syarat-syarat dalam Kepailitan, Adapun syarat-syarat kepailitan yang harus diperhatikan oleh Menteri Keuangan adalah sebagai berikut ${ }^{18}$

"Debitor yang mempunyai dua atau lebih kreditor dan tidak membayar lunas sedikitnya satu utang yang telah jatuh waktu dan dapat ditagih, dinyatakan pailit dengan putusan pengadilan, baik atas permohonannya sendiri maupun atas permohonan satu atau lebih kreditornya."

Berdasarkan penjelasan tersebut Badan Usaha Milik Negara (BUMN) yang berbentuk Perusahaan Umum (Perum) yang memiliki dua atau lebih kreditornya dan tidak membayar lunas sedikitnya satu utang yang telah jatuh waktu dan dapat ditagih, dapat dimohonkan pernyataan pailit oleh Menteri Keuangan. Kemudian apabila Menteri Keuangan telah memperhatikan Keadaan Insolven dan Syaratsyarat Kepailitan maka Menteri Keuangan akan mengajukan pendaftaran pengajuan permohonan pailit kepada Ketua Pengadilan.

Terkait dengan proses pengajuan permohonan pernyataan pailit yang dilakukan oleh Menteri Keuangan harus memperhatikan mengenai dokumen atau surat yang harus dipenuhi atau dilampirkan yaitu sebagai berikut .19

\footnotetext{
${ }^{17}$ Sutan Remy Sjahdeini, Op.Cit, hlm. 153

${ }^{18}$ Pasal 2 ayat (1) UU No. 37 Tahun 2004.

${ }^{19}$ Jono, Op.Cit, hlm. 90
} 
1. Surat permohonan bermaterai yang ditujukan kepada Ketua Pengadilan Negeri/ Pengadilan Niaga.

2. Izin Pengacara/ kartu pengacara.

3. Surat Kuasa Khusus

4. Akta Pendaftaran Perusahaan (Tanda Daftar Perusahaan)/Yayasan/ asosiasi yang dilegalisir (dicap) oleh Kantor Perdagangan paling lambat 1 (satu) Minggu sebelum permohonan didaftarkan.

5. Surat Perjanjian utang atau bukti lainnya yang menunjukkan adanya utang.

6. Perincian utang yang tidak terbayar.

7. Nama serta alamat masing-masing kreditor/ debitor.

Menteri Keuangan tidak membutuhkan Advokat untuk mengajukan permohonan pailit, karena jika mengacu pada Pasal 7 ayat (2) UU No. 37 Tahun 2004 Tentang Kepailitan dan Penundaan Kewajiban Pembayaran Utang Ketentuan sebagaimana dimaksud pada Pasal 7 ayat (1) yakni harus diajukan oleh seorang advokat tidak berlaku dalam hal permohonan diajukan oleh kejaksaan, Bank Indonesia, Badan Pengawas Pasar Modal, dan Menteri Keuangan. Jadi Menteri Keuangan dapat mengajukan langsung permohonan pernyataan pailit terhadap BUMN kepada Ketua Pengadilan tanpa harus melalui advokat.

Pendaftaran permohonan pailit terhadap Badan Usaha Milik Negara (BUMN) oleh Menteri Keuangan harus diajukan sesuai dengan persyaratan yang ditentukan dalam Undang-Undang Nomor 37 Tahun 2004 Tentang Kepailitan dan Penundaan Kewajiban Pembayaran Utang. Adapun mekanisme prosesnya adalah sebagai berikut :

1. Permohonan pernyataan pailit diajukan kepada ketua Pengadilan. ${ }^{20}$ dalam hal ini Menteri Keuangan harus membuat permohonan pernyataan pailit yang diajukan kepada Ketua Pengadilan.

2. Panitera mendaftarkan permohonan pernyataan pailit pada tanggal permohonan yang bersangkutan diajukan, dan kepada pemohon diberikan tanda terima yang ditandatangani oleh pejabat yang berwenang dengan tanggal yang sama dengan tanggal pendaftaran. ${ }^{21}$

\footnotetext{
${ }^{20}$ Pasal 6 ayat (1) UU No. 37 Tahun 2004.

${ }^{21}$ Pasal 6 ayat (2) UU No. 37 Tahun 2004.
}

3. Panitera menyampaikan permohonan pernyataan Pailit kepada Ketua Pengadilan paling lambat 2 (dua) hari setelah tanggal permohonan didaftarkan. ${ }^{22}$

4. Dalam jangka waktu paling lambat 3 (tiga) hari setelah tanggal permohonan pernyataan pailit didaftarkan, pengadilan mempelajari permohonan dan menetapkan hari sidang. ${ }^{23}$

Sebelum Persidangan dimulai pengadilan melalui juru sita melakukan pemanggilan para pihak dengan surat kilat tercatat paling lambat 7 (tujuh) hari sebelum sidang pemeriksaan diselenggarakan. ${ }^{24}$ Pemanggilan tersebut antara lain adalah sebagai berikut : ${ }^{25}$

a. Wajib memanggil Debitor, dalam hal permohonan pernyataan pailit diajukan oleh Kreditor, kejaksaan, bank Indonesia, Badan Pengawas Pasar Modal, atau Menteri keuangan.

b. Dapat memanggil Kreditor, dalam hal permohonan pernyataan pailit diajukan oleh Debitor dan terdapat keraguan bahwa peryaratan untuk dinyatakan pailit sebagaimana dimaksud dalam Pasal 2 ayat (1) telah terpenuhi.

Kemudian akan dilakukan sidang pemeriksaan. Sidang pemeriksaan atas permohonan pernyataan pailit diselenggarakan dalam jangka waktu paling lambat 20 (dua puluh) hari setelah tanggal permohonan didaftarkan. ${ }^{26}$

Permohonan pernyataan pailit yang diajukan oleh Menteri Keuangan harus dikabulkan apabila terdapat fakta atau keadaan yang terbukti secara sederhana bahwa persyaratan untuk dinyatakan pailit sebagaimana dimaksud dalam Pasal 2 ayat (1) telah dipenuhi ${ }^{27}$, isi dari Pasal tersebut adalah mengenai syarat untuk mempailitkan sautu debitor, yakni minimal mempunyai dua atau lebih kreditor yang tidak membayar lunas satu utang yang telah jatuh waktu dan dapat ditagih. kemudian Putusan Pengadilan atas permohonan pernyataan pailit akan diucapkan paling lambat 60 (enam puluh)

\footnotetext{
${ }^{22}$ Pasal 6 ayat (4) UU No. 37 Tahun 2004

${ }^{23}$ Pasal 6 ayat (5) UU No. 37 Tahun 2004.

${ }^{24}$ Pasal 8 ayat (2) UU No. 37 Tahun 2004.

${ }^{25}$ Pasal 8 ayat (1) UU No. 37 Tahun 2004.

${ }^{26}$ Pasal 6 ayat (6) UU No. 37 Tahun 2004.

27 Pasal 8 ayat (4) UU No. 37 Tahun 2004.
} 
hari setelah tanggal permohonan pernyataan pailit didaftarkan. ${ }^{28}$

Putusan Pengadilan wajib memuat pula Pasal tertentu dari peraturan perundangundangan yang bersangkutan dan/atau sumber hukum tak tertulis yang dijadikan dasar untuk mengadili dan pertimbangan hukum dan pendapat yang berbeda dari hakim amnggota atau ketua majelis. ${ }^{29}$

Putusan atas permohonan pernyataan pailit sebagaimana dimaksud pada ayat (6) yang memuat secara lengkap pertimbangan hukum yang mendasari putusan tersebut harus diucapkan dalam sidang terbuka untuk umum dan dapat dilaksanakan terlebih dahulu, meskipun terhadap putusan tersebut diajukan suatu upaya hukum. ${ }^{30}$ Apabila Menteri Keuangan berkeberatan atau merasa Putusan permohonan pailit tidak sesuai maka Upaya Hukum yang dapat diajukan terhadap Putusan permohonan pernyataan pailit adalah kasasi ke Mahkamah Agung, apabila belum puas juga terhadap Putusan Kasasi dapat mengajukan Peninjauan Kembali.

\section{Proses Pengajuan Permohonan Pailit oleh Kreditor BUMN kepada Menteri Keuangan}

Inisiatif dari para kreditor BUMN yang merasa suatu BUMN tidak dapat membayar utangnya yang ingin mempailitkan BUMN tersebut harus melalui Menteri Keuangan. Dalam hal ini para Kreditor harus mengajukan permohonanya kepada Menteri keuangan.

Pengajuan permohonan pailit BUMN ditujukan kepada Menteri Keuangan melalui Biro Hukum bagian hukum kekayaan negara, Perusahaan, dan Informasi Hukum.

Biro hukum bagian Hukum Kekayaan Negara, Perusahaan, dan Informasi hukum mempunyai tugas melaksanakan penelitian/penelaahan legal drafting rancangan peraturan perundang-undangan yang bersifat pengaturan atau penetapan berikut pemrosesannya, dan penelitian/penelaahan aspek yuridis masalah hukum dan/atau pemberian pertimbangan hukum dalam rangka penyelesaian masalah hukum di bidang Barang Milik Negara, kekayaan negara yang dipisahkan, kekayaan negara lainnya, piutang negara,

\footnotetext{
${ }^{28}$ Pasal 8 ayat (5) UU No. 37 Tahun 2004.

${ }^{29}$ Pasal 8 ayat (6) UU No. 37 Tahun 2004.

${ }^{30}$ Pasal 8 ayat (7) UU No. 37 Tahun 2004.
}

lelang, dan perusahaan, serta menyelenggarakan dokumentasi, informasi, dan diseminasi hukum. ${ }^{31}$

Sangat jelas bahwa modal Badan Usaha Milik Negara (BUMN) merupakan dan berasal dari kekayaan negara yang dipisahkan. Dalam penjelasan UU Nomor 19 Tahun 2003 Tentang Badan Usaha Milik Negara yang dimaksud dengan kekayaan negara yang dipisahkan adalah pemisahan kekayaan negara dari Anggaran Pendapatan dan Belanja Negara untuk dijadikan penyertaan modal negara pada BUMN untuk selanjutnya pembinaan dan pengelolaannya tidak lagi didasarkan pada sistem Anggaran Pendapatan dan Belanja Negara.

Berdasarkan uraian diatas Kreditor BUMN harus mengajukan permohonan Pailit kepada Biro Hukum Kementerian Keuangan Bagian Hukum Kekayaan Negara, Perusahaan, dan Informasi hukum agar melakukan penelaahan aspek yuridis masalah hukum, dan memberikan pertimbangan hukum dalam rangka penyelesaian masalah hukum yang terkait dengan bidang kekayaan negara yang dipisahkan atau BUMN. Kemudian setelah Biro hukum Kementerian Keuangan bagian Hukum Kekayaan Negara, Perusahaan, dan Informasi hukum telah memberikan pertimbangan hukum kemudian permohonan pailit yang diajukan oleh kreditor BUMN akan diajukan oleh Biro Hukum kepada Menteri Keuangan untuk segera melakukan permohonan pernyataan pailit BUMN kepada Ketua pengadilan sesuai dengan ketentuan peraturan yang berlaku.

\section{PENUTUP}

\section{A. Kesimpulan}

1. Pengaturan untuk mempailitkan suatu Badan Usaha Milik Negara (BUMN) diatur secara keseluruhan dalam UndangUndang Nomor 37 Tahun 2004 tentang Kepailitan dan Penundaan Kewajiban Pembayaran Utang. Lebih spesifik pengaturannya diatur dalam Pasal 2 ayat (5) Undang-Undang Nomor 37 Tahun 2004. Pengaturan Kepailitan terhadap BUMN memiliki Kekaburan atau multitafsir terkait penjelasan Pasal 2 ayat

\footnotetext{
31 Pasal 68 Peraturan Menteri Keuangan Republik Indonesia Nomor 217/PMK.01/2018 Tentang Organisasi dan Tata Kerja Kementerian Keuangan.
} 
(5) mengenai BUMN yang bergerak dibidang kepentingan publik, UndangUndang Kepailitan tidak memberikan batasan kriteria kepentingan publik secara tegas, hanya menggunakan batasan besaran dan asal modalnya tetapi tidak menjelaskan secara tegas bahwa yang dimaksud dengan kepentingan publik adalah BUMN Perum. Terdapatnya disharmonisasi UndangUndang mengenai kewenangan Menteri Keuangan dalam mempailitkan BUMN Perum juga haruslah memperhatikan asas Lex posteriori derogate legi priori yakni peraturan yang baru mengalahkan atau melumpuhkan peraturan yang lama.

2. Menteri Keuangan memiliki peranan penting dalam pengajuan permohonan peryataan pailit terhadap Badan Usaha Milik Negara (BUMN). Menteri keuangan memiliki peranan untuk mempailitkan suatu BUMN yang bergerak dibidang kepentingan publik (perum) untuk kepentingan perekonomian Negara, atau menjadi salah satu cara untuk menyelamatkan perekonomian Negara melalui kepailitan. Peranan Menteri Keuangan dalam kepailitan BUMN sesuai dengan Undang-Undang Nomor 37 tahun 2004 tentang Kepailitan dan Penundaan Kewajiban Pembayaran Utang adalah sebagai pemohon pernyataan pailit terhadap Badan Usaha Milik Negara (BUMN) yang bergerak di bidang kepentingan Publik atau Perum. Dalam hal kreditor BUMN yang akan mengajukan pailit harus terlebih dahulu mengajukan permohonan kepada Menteri keuangan melalui Biro Hukum bagian Hukum Kekayaan Negara, Perusahaan, dan Informasi hukum yang kemudian akan disampaikan kepada Menteri Keuangan untuk segera mengajukan permohonan pernyataan pailit terhadap BUMN kepada Ketua Pengadilan.

\section{B. Saran}

1. Untuk memberikan kepastian hukum terhadap pengaturan Kepailitan terhadap BUMN dan sekaligus memberikan perlindungan entitas BUMN, kiranya perlu dilakukan Perubahan/Revisi terhadap Pasal 2 ayat (5) dengan mempertegas pengertian BUMN yang bergerak dibidang kepentingan publik adalah BUMN yang berbentuk Perusahaan Umum (Perum). Sekaligus Merevisi Undang-Undang BUMN dengan menunjukkan Menteri Keuangan memiliki kewenangan penuh dalam mempailitkan BUMN Perum.

2. Membuat aturan yang jelas dengan cara merevisi Undang-Undang Nomor 37 Tahun 2004 Tentang Kepailitan dan Penundaan Kewajiban Pembayaran Utang ataupun membuat aturan tersendiri mengenai Kepailitan terhadap BUMN agar lebih mudah untuk diketahui bagaimana Peranan Menteri Keuangan dalam Pengajuan Permohonan Pailit terhadap BUMN. Dan juga agar lebih mudah untuk mengetahui tata cara proses permohonan pernyataan pailit terhadap BUMN.

\section{DAFTAR PUSTAKA}

Andriani Nurdin. 2012. Kepailitan BUMN Persero Berdasarkan Asas Kepastian Hukum. Bandung : P.T. Alumni.

Johnny Ibrahim. 2006. Teori dan Metodologi Penelitian Hukum Normatif. Malang :Bayumedia Publishing.

Soerjono Soekanto. 1986. Pengantar Penelitian Hukum. Jakarta: Universitas Indonesia Press

Viktor M. Situmorang dan Hendri Soekarso.1993. Pengantar Hukum Kepailitan Indonesia. Jakarta: Rineka Cipta

Mark Ingebresten. 2003. Why Companies Fail, terjemahan Emil Salim. Jakarta: Internusa.

H.M.N. Purwosutjipto. (tt). Pengertian dan Pokok-Pokok Hukum Dagang Indonesia. Jakarta: Djambatan

R.Subekti. 1995. Pokok-Pokok Hukum Dagang. Jakarta: Intermesa.

Retnowulan. 1996. Kapita Selecta Hukum Ekonomi dan Perbankan. Jakarta: Seri Varia Yustisia.

Munir Faudy. 2002. Hukum Pailit. Bandung: Citra Aditya Bakti.

Sutan Remy Sjahdeini. 2016. Sejarah, Asas, dan Teori Hukum Kepailitan, Edisi Kedua. Jakarta: Prenadamedia Group. 
Louis E. Levinthal. 1999. The Early History of Bankruptcy Law. New York: Foundation Pres.

Rahayu Hartini. 2017. Konsep Keuangan Negara dan Hukum Kepailitan Indoensia. Malang: Setara Press.

Bintoro, Tjokromidjojo. 1994. Pengantar Administrasi Pembangunan. Jakarta: LP3ES.

Ibrahim R. 1997. Prospek BUMN dan Kepentingan Umum. Bandung: Citra Aditya Bakti.

Refly Harun. 2019. BUMN Dalam Sudut Pandang Tata Negara. Jakarta: Balai Pustaka.

Sudikno Mertokusumo. 2002. Mengenal Hukum (Suatu Pengantar), Cetakan Ketiga. Yogyakarta: Liberty.

Jono. 2008. Hukum Kepailitan. Jakarta: Pt. Sinar Grafika.

\section{Peraturan Perundang-Undangan}

Undang - Undang Nomor 37 Tahun 2004 tentnag Kepailitan dan Penundaan Kewajiban Pembayaran Utang

Undang-Undang Nomor 19 Tahun 2003 tentang Badan Usaha Milik Negara

Kitab Undang-Undang Hukum Perdata (KUH Perdata)

Peraturan Pemerintah Pengganti UndangUndang Nomor 19 Tahun 1960

Undang-Undang Nomor 9 Tahun 1969

Peraturan Menteri Keuangan Republik Indonesia Nomor 21/PMK.01/2018 Tentang Organisasi dan Tata Kerja Kementerian Keuangan.

Peraturan Presiden Nomor 57 Tahun 2020 Tentang Kementerian Keuangan

\section{Internet}

PT Dirgantara Indonesia dinyatakan Pailit, diakses dari https://www.hukumonline.com/berita/bac a/hol17520/pt-dirgantara indonesiadinyatakan-pailit/

Tidak hanya swasta, BUMN pun bisa dipailitkan, diakses dari http://manplawyers.co/2017/08/02/tidakhanya-swasta-bumn-pun-bisa/dipailitkan/ Bankruptcy, diakses dari http://en.wikipedia.org/wiki/Bankruptcy

\section{JURNAL ILMIAH}

Paisol Burlian (2016). Kewenangan Pengajuan Permohonan Pailit Terhadap Perusahaan Asuransi. Jurnal IImu Hukum Magister Hukum. Vol. 1. No. 2. 